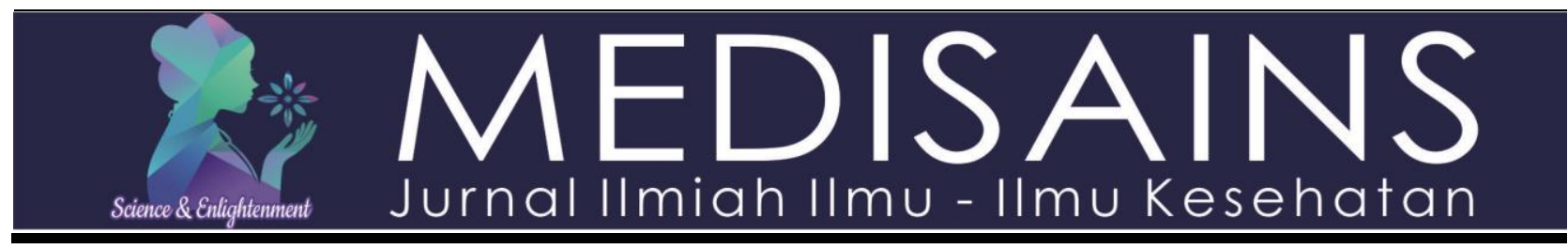

Innovation Article

\title{
Innovative therapeutic pants for children with genu varum and genu valgum
}

\author{
Kurnia Pristiyani ${ }^{1}$, Umi Solikhah, Renaldi Mahesaputra, Falah Dinar Al Hamra ${ }^{2}$ \\ ${ }^{1}$ Department Pediatric of Nursing, Universitas Muhammadiyah Purwokerto, Purwokerto, Central Java, Indonesia \\ ${ }^{2}$ Department of Medicine, Faculty of Medicine, Univesitas Muhammadiyah Purworkerto, Purwokerto, Central Java, Indonesia
}

\section{ARTICLE INFORMATION}

Received: Juni 22, 2019

Revised: Agustus 30, 2019

Available online: Oktober 01, 2019

\section{KEYWORDS}

Therapeutic Pants; Genu Varum; Genu

Valgum; Child; Preschool

\section{CORRESPONDENCE}

Phone: +6289656572192

E-mail: umisolikhah@ump.ac.id

\section{INTRODUCTION}

Epidemiology of genu deformity (genu varum and genu valgum) in the United States was $0.7 \%{ }^{1}$. Nationally, the cases of genu deformity in Indonesia (especially Makassar) have been reported at $19.48 \%$, which consisted of $41.13 \%$ types of genu valgum while genu varum was $58.86 \%{ }^{2}$. The diseases cases in Banyumas Regency have not been reported. The effects of experiencing genu varum and genu valgum in children are pain in the middle of the knee and arthritis during their adult growth, increased pressure in the muscle compartment, growth disorders and deformities. ${ }^{3,4}$.

Therapeutic management of genu deformity ${ }^{5}$ can be implemented with both non-surgical and surgical therapy ${ }^{6-8}$. The success rate of the therapeutic management depends on the patient's age, and the degree of joint damage ${ }^{6}$. Non-surgical therapy is usually applied for degree I and II in patients who are less than 3 years old, while degrees III - VI is for patients who are older than 3 years old and or for those who are failed in non-surgical therapy. Deformity of genu therapy degree III-VI usually requires surgery; it also usually results permanent sequelae ${ }^{9,10}$.

Previous studies in stage I and II of genu deformity with the use of braces (brace/splint) ${ }^{11}$ is the right way to improve the angle of the proximal tibia varus ${ }^{5,15}$. One method of brace installations that is often used is Knee ankle foot orthosis (KAFO) ${ }^{9,12}$. This method fixes the knee in the extension position and gives the medial space to become valgus. This brace is used 23 hours a day, for 2 years or depending on the degree of varus angulation $9,10,13,14$.

The therapy is still limited in patients with genu deformity, so it needs the latest product innovations to prevent the disease. One of them is the development of genu varum and genu valgum therapy pants that provides comfort and has an anchoring device to keep the foot position looks normal when the child is moving and walking. The objec- 
tive of this study is to prevent genu varum and genu valgum in toddlers' feet by providing them comfortable feeling when they are mobilizing.

\section{METHOD}

The researchers used Research and Development (R\&D) approach in this study ${ }^{15,16}$. It consisted of 3 phases, namely phase I, II, and III or product trials ${ }^{17-19}$.

Phase I of this research was a literature study that aimed to find a comparison of cloth materials suitable for the pants and interviews about the comfort of wearing pants. The results of interviews with 10 respondents resulted the data that they need tools that are useful to prevent and provide comfort to toddlers who experience disorder of genu varum and genu valgum. Researchers figured out comparisons between existing products with the pants that will be produced in terms of fabric materials and its shape. The fabric used as the basic material for producing these therapeutic pants was cotton cloth and the material used for cushioning was foam and self-adhesive hook and loop (velcro).

Phase II of this research was the stage of product development with reference to the results of Phase I. Researchers designed therapeutic pants in accordance with the size according to anthropometry (national data). This innovative pants were made with cotton cloth that is equipped with foam on the sides to increase comfort in the use. The zipper on the side of the pants functions to make it easier to get self-adhesive hook and loop inside the pants. While the fabric adhesive to tighten the pants according to the shape of a toddler's feet. In addition, the rubber on the waist pants for easy adjustment of waist size.
Phase III of this research was the trial phase. The type of study is experimental ${ }^{20}$. The population were children (toddlers) having genu varum and genu valgum foot disorder with a total sample of 5 people ${ }^{21}$. The assessed variables were the level of comfort and satisfaction in the use of this innovative pants. The instrument was a questionnaire including structured statements about comfort and satisfaction. Data analysis which used by researchers was simple descriptive analysis.

\section{RESULTS}

From the literary study in phase I, it was obtained that materials used to make the therapeutic pants were cotton cloth fabric and foam. In the second phase of the research, it was also obtained that designs and shapes of the pants were as needed as shown in the Figur 1.

Figure 1 shows the product design of therapeutic pants that is equipped with fabric self-adhesive hook and loop. Therapeutic pants made of cotton and equipped with foam. The use of this therapeutic pants can make the respondent's feet look like normal in general. While figures 2 and 3 show the use of therapeutic pants in children with genu varum and genu valgum.

The results of product trials or phase III of this study involved 5 respondents and it obtained the results as follow, the use of therapeutic pants in children (toddlers) provides comfort and satisfaction. Therapeutic pants were tested on 5 respondents with various gender. Before the respondent wore the therapeutic pants, the respondent's family first filled out a questionnaire including a questionnaire of safety and comfort level. The results of the comfort level questionnaire showed that respondents felt comfortable and satisfied in wearing the therapeutic pants; their toddlers did not cry while wearing the pants

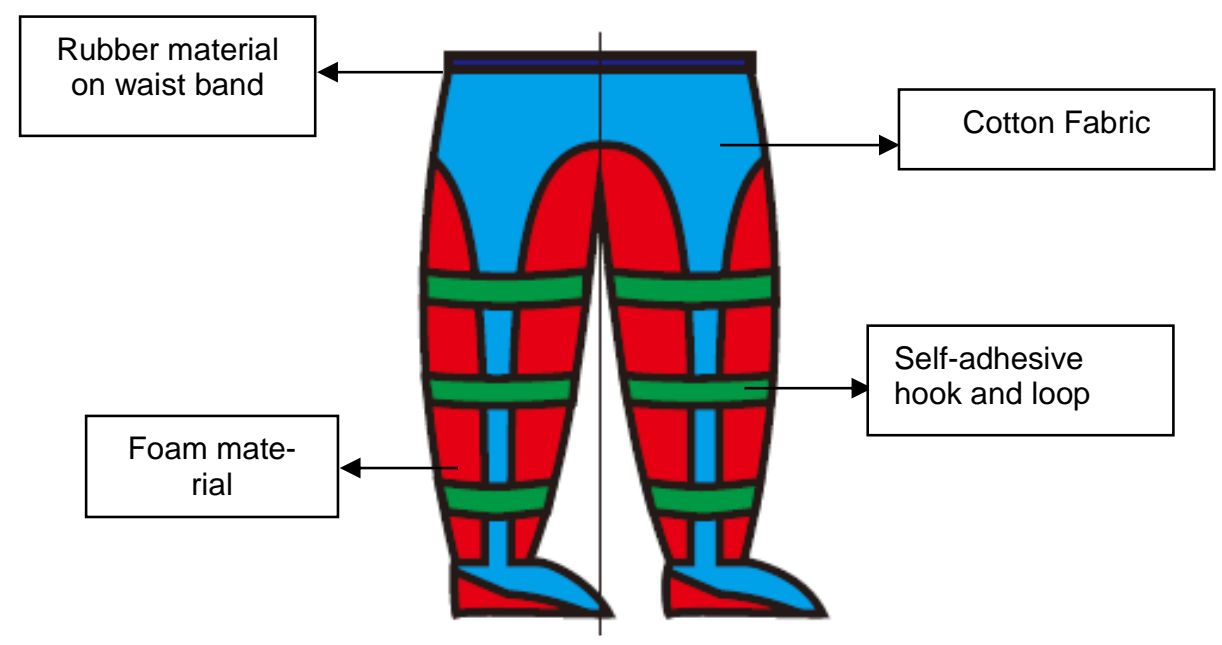

Figure 1. Design of innovative pants 


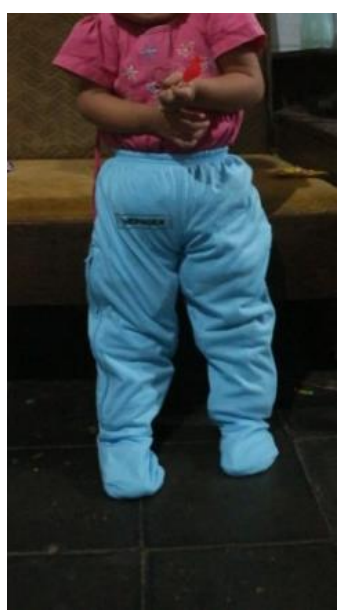

Figure 2. The use of therapeutic pants in a child with genu varum

\section{DISCUSSION}

From the trial results on five respondents, all of them stated that they felt safe and comfortable. That was because of its fabric material; the therapeutic pants were made of cotton fabric and foam that is soft and comfortable to wear. Cotton cloth is a fabric that is $100 \%$ natural plant fiber, contains no chemicals, and has hypo allergenic material. In addition, this fabric is more comfortable to wear because the fibers are hollow like air ventilation so the skin can 'breathe'. The variable confidence and comfort obtained from the five respondents indicated that the therapeutic pants are comfortable when used and they become easy to move outside their homes.

For that reason, the researchers produce this therapeutic pants which is made of soft materials and attractive designs for the users. In a previous study conducted in the United States, iron Therapy Pants were used to test ankle performance and the presence of a disc that was positioned in the knees of children to slow growth temporarily, but the outside part of the knee would keep growing ${ }^{22}$. Therefore, the researcher did a modification ${ }^{23}$ by giving priority to the respondents' comfort as well as the materials used; it is also designed to prevent the occurrence of leg disorders of both genu varum and genu valgum in children. To prove the pants are able to prevent the disorders of the foot, it requires a long time. In addition, the researchers selected the materials because they are affordable by the respondents.

\section{CONCLUSIONS AND RECOMMENDATION}

The results of this therapeutic pants product development are proven to provide comfort when children with genu varum and genu valgum are mobilizing daily. For mothers who have children with the feet disorders, they are expected to use this product for their children as a medical

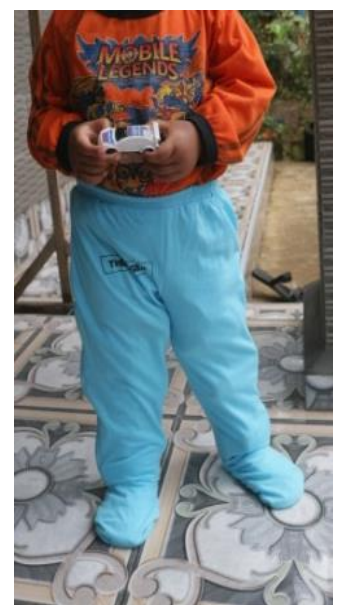

Figure 3. Use of therapeutic pants in a child with genu valgum

therapy. The product development does not stop here, it needs development and measurement of other variables, so that the researchers can produce more perfect therapeutic pants product.

\section{REFERENCES}

1. Pettifor JM. Calcium and vitamin D metabolism in children in developing countries. Ann Nutr Metab. 2014;64(suppl 2):15-22. doi:10.1159/000365124

2. Yuniarti R. Hubungan Antara Tingkat Genu Varum dan Genu Valgum dengan Kualitas Keseimbangan Dinamis pada Siswa Sekolah Dasar Usia $7-12$ tahun di Kabupaten Takalar Makassar. 2017.

3. Thandrayen K, Pettifor JM. The roles of vitamin D and dietary calcium in nutritional rickets. Bone Reports. doi:10.1016/j.bonr.2018.01.005

4. Fallatah S, Felemban M, Farran A, Alharbi L, Borgola S. Awareness of common paediatric orthopaedic problems among paediatricians and family medicine physicians. J Taibah Univ Med Sci. 2018;13(4):338-343.

doi:10.1016/j.jtumed.2018.04.008

5. Putra IGM. Penyakit Blount - Diagnosis dan Tatalaksana. 2018;45(2):261-263.

6. Munns CF, Shaw N, Kiely M, et al. Resumo das características do medicamento - kalydeco 150 mg. 2016;101(February):394-415. doi:10.1195/000443136

7. Pablo Castañeda, Bradford Urquhart, Elroy Sullivan RH. Hemiepiphysiodesis for the Correction of Angular Deformity About the Knee. $J$ Pediatr Orthop. 2008;28(2):188-191. doi:10.1097/BPO.0b013e3181653ade

8. Wong D. Pedoman Klinis Keperawatan Pediatrik. Jakarta: EGC; 2003.

9. Ferguson,Jamie dan Wainwright $A$. Tibial bowing in children. Orthop Trauma. 2013;27(1):30-41. doi:https://doi.org/10.1016/j.mporth.2012.11.001

10. Shinohara $Y$, Kamegaya M, Kuniyoshi K, Moriya $\mathrm{H}$. Natural history of infantile tibia vara. J Bone Jt Surg - Ser B. 2002;84(2):263-268. doi:10.1302/0301- 
620X.84B2.11821

11. Martínez G, Drago S, Avilés C, Ibañez A, Hodgson F, Ramírez C. Distal femoral hemiepiphysiodesis using screw and non-absorbable filament for the treatment of idiopathic genu valgum. Preliminary results of 12 knees. Orthop Traumatol Surg Res. 2017;103(2):269-273.

doi:10.1016/j.otsr.2016.11.014

12. Sawicki GS, Ferris DP. A pneumatically powered knee-ankle-foot orthosis (KAFO) with myoelectric activation and inhibition. I Neuroeng Rehabil. 2009;6(1):1-16. doi:10.1186/1743-0003-6-23

13. Kawu AA, Salami OOA, Olawepo A, Ugbeye MA, Yinusa W, Odunubi OO. Outcome analysis of surgical treatment of Blount disease in Nigeria. Niger J Clin Pract. 2012;15(2):165-167. doi:10.4103/1119-3077.97340

14. Rathjen, Neil dan Saran K. Guided Growth for the Correction of Pediatric Lower Limb Angular Deformity. Am Acad Orthop Surg. 2010;18(9). https://insights.ovid.com/pubmed?pmid=20810934

15. Sugiyono. Metode Penelitian Pendidikan Pendekatan Kuantitatif, Kualitatif, Dan $R$ \& $D$. Bandung: Alfabeta; 2009.

16. Sukmadinata. Metode Penelitian Pendidikan. Bandung: Remaja \& Osdakarya; 2011.

17. Chebii RJ. Effects of Science Process Skills
Mastery Learning Approach on Secondary School Students' Achievement and Acquisition of Selected Chemistry Practical Skills in Koibatek District Schools, Kenya. 2011;3(8):1291-1296.

18. Zissimopoulos A, Fatone S, Gard SA. Biomechanical and energetic effects of a stancecontrol orthotic knee joint. J Rehabil Res Dev. 2007;44(4):503-513.

doi:10.1682/JRRD.2006.09.0124

19. Adi R. Metodologi Penelitian Sosial Dan Hukum. Jakarta: Granit; 2004.

20. Knight KL. Study/Experimental/Research design: Much more than statistics. $J$ Athl Train. 2010;45(1):98-100. doi:10.4085/1062-605045.1 .98

21. Zhong B. How to calculate sample size in randomized controlled trial? J Thorac Dis. 2009;1(1):51-54

22. Alfatafta $\mathrm{HH}$, Hutchins S, Liu A, Jones R. Effect of a knee-ankle-foot orthosis on knee kinematics and kinetics in an individual with varus knee alignment. $J$ Prosthetics Orthot. 2016;28(4):186-190. doi:10.1097/JPO.0000000000000111

23. Surya W, Mustamu RH. Analisis Pengembangan Produk Pada Perusahaan Tepung Terigu di Surabaya. J Manaj Bisnis. 2013;1(1). http://publication.petra.ac.id/index.php/manajemen -bisnis/article/view/241. 